\title{
Sociologia da Infância / Sociology of Childhood
}

https://doi.org/10.21814/uminho.ed.36.55

\section{Alan Prout}

Professor Emeritus, University of Leeds, United Kingdom 



\section{Sociologia da Infância}

De modo geral, a Sociologia da Infância refere-se a um conjunto de literatura e pesquisa académica que aplica as teorias, os conceitos e perspetivas sociológicas à infância. A diversidade disciplinar da Sociologia reflete-se na Sociologia da Infância que, consequentemente, forma um campo um pouco díspar de discurso teórico, empírico e metodológico. 0 que a distingue de outras subdisciplinas sociológicas é o seu foco central na vida social das crianças e da infância pensada como (pelo menos em parte) uma instituição social.

Enquanto pensadores como Sócrates (e anteriores) tiveram interesse em explorar a natureza da infância, notoriamente nos casos de John Locke e de Jean Jacques Rousseau, os sociólogos clássicos dos fins do século XIX e de meados do século $X X$, prestaram pouca atenção às crianças e à infância.

Marx e Engels escreveram acerca do trabalho infantil na acumulação primitiva do capital e Weber viu no inculcar das ideias de poupança e de trabalho árduo, nas crianças das famílias protestantes, uma das circunstâncias para a emergência do capitalismo. Ambos, contudo, tomaram a infância como garantida e não questionaram as suas relações, os seus processos e as suas formas institucionais.

Durkheim foi invulgar, tentando entender a infância como um tema de direito próprio, nalguns aspetos codificando o que estava implícito em Marx e em Weber e, nesse processo, iniciando o que se haveria de tornar a norma do século $X X$, a visão sociológica da infância como um período de socialização durante o qual a natureza particular da criança é subjugada e a ordem social é interiorizada, uma norma mais tarde codificada por Talcott Parsons. Mesmo assim, a Sociologia tinha pouco a dizer sobre a infância, reconhecendo implicitamente a hegemonia da Psicologia, especialmente da Psicologia do Desenvolvimento (que se aliou à Medicina pediátrica) com a sua ênfase na criança individual e no seu (quase sempre o dele) normal desenvolvimento.

A Sociologia da Infância contemporânea surgiu durante os anos 80 , quando sociólogos (primeiramente no Reino Unido, Suécia, Dinamarca, Noruega, 
Alemanha e mais tarde mundialmente) insatisfeitos com o padrão sociológico da época, gradualmente se reuniram numa série de redes e de conferências.

Os motivos das suas críticas eram vários: a sociologia interacionista estabeleceu uma alternativa ao funcionalismo estrutural parsoniano, olhando para as ordens sociais como construídas através de interações locais e reconfigurando as crianças como agentes interpretativos; seguindo Ariès, pesquisas históricas sugerem diversidade cultural e social na infância ao longo do tempo, tal como o registo antropológico documentava a diversidade no espaço; o construcionismo social chamou a atenção para práticas discursivas e linguísticas na formação das múltiplas versões da infância; enquanto as noções de estrutura social (classicamente as de classe, mas mais tarde incluindo género, etnia e deficiência) sugerem olhar para a infância como um traço permanente da ordem social, talvez parte de uma ordem geracional. Estes elementos foram reunidos por James e Prout numa declaração programática da Sociologia da Infância frequentemente referida como o "novo paradigma".

O trabalho inicial de criar uma subdisciplina continuou até ao presente, quatro décadas (de 1980 até 2020) durante as quais os sociólogos têm, em milhares de estudos, investigado empiricamente as crianças como agentes sociais e as infâncias como formações sociais.

Ao mesmo tempo, foram desenvolvidos procedimentos metodológicos e éticos para incluir as crianças no trabalho sociológico, ultrapassando muitos obstáculos, reais ou imaginários, para a sua participação. Este trabalho também explorou a diversidade teórica subjacente à Sociologia da Infância.

Quatro grupos teóricos principais foram identificados e enraizados no desenvolvimento mais amplo do pensamento sociológico: estudos de cenários locais (tais como escolas, bairros e hospitais) nos quais as crianças participaram em interação umas com as outras e com os adultos; estudos que realçam as diferenças de poder frequentemente encontradas nas relações criança-adulto, muitas vezes usando direitos como modo de enquadramento de questões numa forma paralela à sociologia feminista e desenvolvendo noções de uma estrutura geracional; estudos documentando as condições sociais das vidas das crianças, usando comparações estatísticas, sociais, nacionais; explorações construcionistas sociais de práticas discursivas através das quais versões diferentes da infância são criadas em diferentes circunstâncias e cenários. Estas quatro abordagens foram 
frequentemente combinadas de formas diferentes explorando as sobreposições e as tensões entre elas.

Enquanto o trabalho acima discutido formou a corrente principal do trabatho sociológico sobre a infância, os últimos vinte anos viram isto gradualmente desafiado por aquilo que se tem chamado "terceira "ou "nova vaga" de estudos da infância. Estes realçaram a forma como o programa original da sociologia da infância procurou encontrar um lugar para as crianças e para a infância na sociologia como uma disciplina existente.

Ao mesmo tempo (dos anos 1990 em diante) a disciplina em si foi posta em questão e foi confrontada com muitos problemas. As suas metáforas centrais, tais como a noção de estrutura social estável, muitas vezes identificada com o estado nação, foram sendo vistas como desadequadas em relação a formas de vida social em rede, mais móveis e fluidas, emergindo de inovações tecno-sociais dos fins do século vinte, novos fenómenos muitas vezes centrais para a infância contemporânea.

Ao mesmo tempo, entender a vida social como uma área separada e diferente do mundo natural passou a ser visto como insustentável. Uma consequência disto foi questionar o excecionalismo humano que em primeiro lugar tornou a sociedade num fenómeno linguístico ou discursivo.

Sem rejeitar a importância da linguagem na construção das relações sociais, novas abordagens (tais como aquelas das quais Latour e Callon foram precursores) redescobriram a importância do mundo material (incluindo organismos biológicos e tecnológicos).

Críticos no interior da Sociologia da Infância, tais como Prout e Lee, começaram a sugerir que estas abordagens materialistas relacionais emergentes têm muito para oferecer à Sociologia da Infância.

Isto pode implicar um afastamento do impulso inicial de conquistar um nicho para a infância na sociologia convencional na construção de um campo de estudo interdisciplinar para a infância, localizado dentro de uma ampla investigação discursiva sobre a vida humana como produto tanto da natureza como da cultura, em todos os seus complexos emaranhados. Estas perspetivas foram aceites por muitos jovens académicos da área e o que emerge do debate irá definir o futuro do estudo social da infância. 


\section{The Sociology of Childhood}

In general terms, the sociology of childhood refers to a body of academic research and writing that applies sociological theories, concepts and perspectives to childhood. The disciplinary diversity of sociology is reflected in childhood sociology, which consequently forms a somewhat disparate field of theoretical, empirical and methodological discourse. What distinguishes it from other sociological sub-disciplines is its central focus on the social life of children and childhood thought of as (at least in part) a social institution.

Whilst thinkers from Socrates (and before) have been interested in exploring the nature of childhood, famously in the cases of John Locke and Jean-Jacques Rousseau, classical sociologists of the late nineteenth and mid-twentieth century paid relatively little attention to children or childhood.

Marx and Engels wrote about child labour in the primitive accumulation of capital; Weber saw in the Protestant family's inculcation of children into thrift and hard work one of the historical circumstances for the emergence of capitalism.

Both, however, took childhood for granted and left unquestioned its relations, processes and institutional forms.

Durkheim was unusual in trying to understand childhood as a topic in its own right, in some respects codifying what was implicit in Marx and Weber. In the process, he initiated what was to become the standard twentieth century sociological view of childhood as a period of socialization during which the child's particular nature is tamed and the social order internalised, a standard account later codified by Talcott Parsons. Even so, sociology had little to say about childhood, implicitly recognising the hegemony of psychology, especially developmental psychology (which was closely allied to paediatric medicine) with its emphasis on the individual child and his (nearly always his) normal development.

The contemporary sociology of childhood first emerged during the 1980s, from sociologists (at first in the UK, Sweden, Denmark, Norway, and Germany, later worldwide) dissatisfied with the prevailing sociological account, who gradually came together through a number of networks and conferences.

The sources of their critique were several: interactionist sociology set out an alternative to Parsonian structural functionalism, seeing social orders as 
constructed through local interactions and refiguring children as interpretive agents; following Ariès, historical research suggested social and cultural diversity in childhood over time, just as the anthropological record documented diversity over space; social constructionism drew attention to discursive and linguistic practices in the formation of multiple versions of childhood; whilst notions of social structure (classically those of class but latterly including gender, ethnicity and disability) suggested looking at childhood as a permanent feature of social order, perhaps part of a generational order. These elements were drawn together by James and Prout into a programmatic statement of the sociology of childhood often referred to as the "new paradigm".

The initial work of creating a sub-discipline has continued right up to the present time, four decades later (1980 to 2020) during which sociologists have, in thousands of studies, empirically investigated children as social actors and childhoods as social formations.

At the same time, methodological and ethical procedures for including children in sociological work have been developed, overcoming many real or imagined obstacles to their participation. This work also explored the theoretical diversity underpinning the sociology of childhood.

Four main theoretical clusters were identified and rooted in the broader development of sociological thinking: studies of local settings (such as schools, neighbourhoods and clinics) in which children participated in an interaction with one other and with adults; studies that emphasised the different levels of power often found in child-adult relations, often using rights as a way of framing questions in ways parallel to feminist sociology and eventually developing notions of a generational structure; studies documenting the social conditions of children's lives, often employing national, social statistical comparisons; social constructionist explorations of the discursive practices through which different versions of childhood are created in different circumstances and settings. These four approaches were frequently combined in different ways that explored the overlaps and tensions between them.

Whilst the work discussed above formed the mainstream of sociological work on childhood, the last twenty years have seen this gradually challenged by what have been called "third" or "new wave" studies of childhood. These highlight how the original programme of the sociology of childhood sought to find a place for children and childhood in sociology as an extant discipline. 
At the same time (from the 1990s onwards), that discipline itself was in question as it confronted a number of problems. Its core definitions, such as the notion of a stable social structure, often identified with the nation state, were increasingly seen as inadequate compared to the more mobile, fluid and networked forms of social life emerging from the socio-technical innovations of the late twentieth century. These new phenomena are often central to contemporary childhood.

At the same time, understanding social life as a sphere separate and different from the natural world came to be seen as untenable. One consequence of this was to question the human exceptionalism that made society primarily a discursive or linguistic phenomenon.

Without rejecting the importance of language in the construction of social relations, new approaches (such as those pioneered by Latour and Callon) rediscovered the importance of the material world (including biological and technological entities).

Critics from within the sociology of childhood, such as Prout and Lee, began to suggest that these emerging relational materialist approaches have much to offer the sociology of childhood.

This may entail a shift away from the initial impulse to carve out a niche for childhood in conventional sociology towards constructing an interdisciplinary field of study for childhood, located within a broad discursive and material enquiry into human life as a product of both nature and culture in all their complex entanglements. These perspectives have been taken up by many younger scholars in the field, and what emerges from this debate will shape the future of the social study of childhood.

\section{Referências / References}

Christensen, P. \& James, A. (2017). Research with Children: Perspectives and Practices. Abingdon: RoutledgeFalmer.

James, A., Jenks, C. \& Prout, A. (1998). Theorising Childhood, Cambridge: Polity Press.

Kraftl, P. (2020). After Childhood: Re-thinking Environment, Materiality and Media in Children's Lives. Abingdon: Routledge.

Prout, A. (2005). The Future of Childhood: Towards the interdisciplinary study of children. Abingdon: RoutledgeFalmer. 